\title{
FAKTOR-FAKTOR YANG BERHUBUNGAN DENGAN KEMANDIRIAN PETANI DALAM PENGAMBILAN KEPUTUSAN UNTUK KEBERLANJUTAN USAHATANI (Kasus: Petani di Desa Sukaharja - Kabupaten Bogor)
}

\author{
Malta \\ Fakultas Matematika dan Ilmu Pengetahuan Alam IPA, Universitas Terbuka Bogor \\ E-mail: malta@ut.ac.id
}

\begin{abstract}
ABSTRAK. Kesiapan menghadapi era globalisasi membutuhkan kemandirian petani dalam daya saing, hal ini berkaitan dengan kemampuan petani dalam me-manage usahataninya guna menjamin kualitas produk dan keberlanjutan usahatani. Penumbuhan kemandirian petani, perlu diarahkan agar mereka dengan kekuatan dan kemampuan dirinya bekerjasama untuk mencapai segala yang dibutuhkan. Tujuan penelitian ini adalah menganalisis faktor-faktor yang berhubungan tingkat kemandirian petani dalam pengambilan keputusan untuk keberlanjutan usahatani di Desa Sukaharja Kabupaten Bogor. Jenis penelitian yang digunakan adalah penelitian deskriptif korelasional, untuk melihat hubungan antara peubah penelitian dan menguji hipotesis. Penelitian dilakukan pada bulan September sampai Desember 2013 di Desa Sukaharja Kabupaten Bogor Provinsi Jawa Barat. Populasi penelitian adalah semua petani yang memiliki lahan sendiri dalam berusahatani, yaitu sebanyak 67 petani. Sampel penelitian diambil sebanyak 30 petani. Penarikan sampel dilakukan secara acak (random sampling). Pengujian hipotesis dilakukan dengan menggunakan analisis uji korelasi Rank Spearman. Hasil penelitian menunjukkan bahwa faktor yang penting diperhatikan untuk meningkatkan kemandirian petani di Desa Sukaharja Kabupaten Bogor dalam pengambilan keputusan untuk keberhasilan usahatani adalah: keaktifan mencari informasi yang berhubungan dengan usahatani dan interaksi dengan penyuluh.
\end{abstract}

Kata kunci: petani, kemandirian, keberlanjutan usahatani

\section{FACTORS RELATED TO FARMER INDEPENDENCE IN DECISION MAKING ON SUSTAINABLE AGRIBUSINESS (A case study of farmers in Sukaharja Village, Bogor Regency)}

\begin{abstract}
Readiness of the era of globalization requires a farmer independence in competitiveness, it relates to the ability of farmers in managing his farm in order to ensure product quality and sustainability of farming. Growth farmer independence, must be directed so that their strength and her ability to cooperate to achieve all that is required. The purpose of this study was to analyze the factors that relate the level of independence of farmers in decision-making for sustainable farming in the village of Sukaharja Bogor. This type of research is descriptive correlational research, to see the relationship between the study variables and test hypotheses. The study was conducted from September to December 2013 in the village Sukaharja Bogor Regency, West Java Province. The study population were all farmers who own land in farming, as many as 67 farmers. Samples were taken as many as 30 farmers. Sampling was carried out at random (random sampling). Hypothesis testing is done by using the Spearman rank correlation test analysis. The results showed that many important factors to increase the independence of farmers in the village Sukaharja Bogor Regency in decision-making to the success of farming are: activeness searching for information related to the farming and interaction with the extension.
\end{abstract}

Key words: farmer, self-reliance, sustainability of farming

\section{PENDAHULUAN}

Sejak memasuki abad ke-21 perekonomian negara-negara di seluruh dunia tidak ada yang lepas dari pengaruh liberalisasi perekonomian dunia. Tata ekonomi dunia tidak lagi dikekang oleh batas-batas wilayah maupun batas sistem pemerintahan. Setiap negara berlomba untuk menghasilkan produksi barang maupun jasa dalam mengisi pasar domestik maupun internasional. Indonesia merupakan negara yang menjadi tujuan pasar potensial bagi produk dari luar negeri, termasuk komoditas tanaman pangan dan hortikultura. Menurut data BPS (2013), rata-rata setiap bulannya total impor sayuran dari luar negeri yang masuk ke Indonesia adalah 42 ribu ton, sedangkan impor buah-buahan 43 ribu ton (http://www.bps.go.id).

Membanjirnya produk impor, menjadikan petani semakin terhimpit berbagai kesulitan untuk mem- pertahankan usahatani yang dikelolanya, mengingat harus bersaing dengan produk dari luar negeri. Pada sisi lain, nasib petani saat ini semakin dihimpit dengan berpacunya kebutuhan keluarga yang harus dipenuhi, menyusul kenaikan harga bahan bakar minyak yang menyebabkan melambungnya harga kebutuhan pokok lainnya. Petani harus berusaha keras memenuhi kebutuhan untuk konsumsi, sekaligus menjaga kelangsungan usahataninya. Seiring dengan berjalannya waktu, kesejahteraan petani semakin terpuruk dalam ketidak berdayaan dan semakin jauh dari memiliki kemandirian dalam melakukan kegiatan usahataninya.

Menghadapi sistem persaingan perdagangan dunia, sangat penting untuk mempersiapkan petani dalam menerapkan sistem perdagangan modern dengan memperhatikan mutu produk dan memberi kepuasan optimal bagi konsumen yang terdapat di pasar, sehingga mampu bersaing dengan produk impor (Deptan 
IPB, 1999). Kesiapan menghadapi era globalisasi membutuhkan kemandirian petani dalam daya saing, hal ini berkaitan dengan kemampuan petani dalam memanage usahataninya guna menjamin kualitas produk dan keberlanjutan usahatani.

Kemandirian dimaksudkan sebagai perwujudan kemampuan seseorang untuk memanfaatkan potensi dirinya sendiri dalam memenuhi kebutuhan hidupnya, yang dicirikan oleh kemampuan dan kebebasan menentukan pilihan yang terbaik. Kemandirian akan memungkinkan seseorang meningkatkan kualitas dirinya yang mencakup aspek kualitas hidup, kerja, karya, dan pikir (Hubeis, 2002). Slamet (1995) menekankan bahwa untuk menumbuhkan dan membina kemandirian petani, perlu diarahkan agar mereka dengan kekuatan dan kemampuan dirinya bekerjasama untuk mencapai segala yang dibutuhkan.

Petani di Desa Sukaharja Kabupaten Bogor telah lama menggeluti usahatani, namun masih jauh dari kriteria petani yang mandiri. Seperti, harga hasil panen ditentukan pedagang pengumpul yang datang, petani tidak punya kemandirian menentukan harga jual hasil panen. Petani masih terjebak dalam "penguasaan" pihak lain, sehingga tidak bebas menentukan pilihan yang terbaik dalam berusahatani.

Petani, dalam berusahatani, tidak saja dituntut berorientasi pada produk yang dibutuhkan pasar, tetapi juga harus mampu menciptakan pasar, efisien, dan memiliki daya saing. Sumardjo (1999) menyebutkan bahwa petani dituntut untuk memiliki aspirasi, kreatif, mampu mengambil keputusan yang menguntungkan, inovatif, dan tangguh dalam berusahatani.

Ketidakpastian dalam berusahatani, menjadikan sebagian kecil petani di lokasi penelitian beralih dari berusahatani menjadi pengrajin. Ada juga yang menjual lahan pertanian miliknya dan sebagian lagi membiarkan lahannya tidak digarap. Jika tidak ada upaya untuk memandirikan petani, maka keberlanjutan usahatani di lokasi penelitian terancam habis/berhenti.

Oleh karena itu perlu diupayakan peningkatan kemandirian petani dalam pengambilan keputusan untuk keberlanjutan usahatani. Berdasarkan hal tersebut, maka rumusan masalah dalam penelitian adalah: faktor-faktor apa yang berhubungan dengan tingkat kemandirian petani dalam pengambilan keputusan untuk keberlanjutan usahatani di Desa Sukaharja Kabupaten Bogor?

Berdasarkan latar belakang dan rumusan masalah, maka tujuan penelitian adalah: menganalisis faktor-faktor yang berhubungan dengan tingkat kemandirian petani dalam pengambilan keputusan untuk keberlanjutan usahatani di Desa Sukaharja Kabupaten Bogor.

\section{METODE}

Jenis penelitian yang digunakan adalah penelitian deskriptif korelasional, untuk melihat hubungan antara peubah penelitian dan menguji hipotesis. Penelitian dilakukan pada bulan September sampai Desember 2013 di Desa Sukaharja Kabupaten Bogor Provinsi Jawa Barat. Populasi penelitian adalah semua petani yang memiliki lahan sendiri dalam berusahatani, yaitu sebanyak 67 petani. Sampel penelitian diambil sebanyak 30 petani. Penarikan sampel dilakukan secara acak (random sampling). Penelitian terdiri dari satu peubah bebas yaitu karakteristik sosial petani (X) dan satu peubah terikat yaitu kemandirian petani dalam pengambilan keputusan untuk keberlanjutan usahatani (Y).

Data yang dikumpulkan terdiri dari data primer dan data sekunder. Data primer diperoleh dengan mendatangi dan melakukan wawancara terhadap responden dengan berpedoman pada kuesioner yang kemudian diklarifikasi dengan wawancara mendalam. Data sekunder berupa data kelompok tani, diperoleh dari dokumen pelengkap yang terdapat pada kelompok tani di Desa Sukaharja Kabupaten Bogor. Pengujian hipotesis adalah dengan menggunakan analisis uji korelasi Rank Spearman.

\section{HASIL DAN PEMBAHASAN}

\section{Karakteristik Sosial Petani}

Pendidikan formal yang dimaksud dalam penelitian adalah jumlah tahun petani dalam mengikuti proses belajar mengajar di bangku sekolah formal. Petani dengan tingkat pendidikan rendah disebabkan oleh keadaan ekonomi yang kurang menguntungkan dan rendahnya kesadaran orang tua jaman dulu dalam menyekolahkan anaknya ke jenjang yang lebih tinggi, disamping ketiadaan sarana pendidikan lanjutan tingkat menengah di lokasi penelitian. Kisaran pendidikan petani adalah $0-12$ tahun dengan rata-rata tahun pendidikan selama 5,4 tahun dan terdapat sejumlah kecil (6,7 persen) petani yang tidak pernah duduk di bangku sekolah formal, tetapi seluruh responden dalam penelitian ini mampu membaca dan menulis. Kemampuan ini merupakan modal dasar yang utama dalam memperoleh dan memahami berbagai informasi dan menambah wawasan dalam berusahatani.

Pendidikan memudahkan bagi diri petani dan kelompok masyarakat dalam menerima informasi yang berasal dari berbagai sumber yang dapat memberikan nilai tambah (add value) bagi diri petani yang dapat dijadikan dasar dalam menentukan pilihan terbaik dalam kegiatan berusahatani. Rendahnya tingkat pendidikan formal petani di lokasi penelitian menyiratkan rendahnya kualitas sumber daya manusia petani. Padahal melalui pendidikan, didapatkan tambahan wawasan dan pengalaman belajar sebagai bekal dalam kehidupan termasuk bekal dalam menjalankan usahatani dengan baik. Sebagaimana Sidi \& Setiadi (2005) menyatakan bahwa pendidikan adalah upaya membekali seseorang dengan ilmu agar ia mampu 
menghadapi dan menjalani kehidupannya dengan baik, serta mampu mengatasi permasalahannya secara mandiri. Sebagian besar $(56,7$ persen) petani di lokasi penelitian memiliki pendidikan di bawah 7 tahun.

Tabel 1 Deskripsi karakteristik sosial petani

\begin{tabular}{|c|c|c|c|}
\hline No & $\begin{array}{c}\text { Karakteristik } \\
\text { Sosial Petani (X) }\end{array}$ & Kategori & Persen \\
\hline 1 & $\begin{array}{l}\text { Pendidikan } \\
\text { formal }\end{array}$ & $\begin{array}{l}\text { Tidak sekolah } \\
\text { Tidak tamat SD } \\
\text { Tamat SD } \\
\text { Tidak tamat SLTP } \\
\text { Tamat SLTP } \\
\text { Tamat SLTA }\end{array}$ & $\begin{array}{c}6,7 \\
23,3 \\
26,7 \\
10 \\
10 \\
23,3\end{array}$ \\
\hline 2 & $\begin{array}{l}\text { Pengalaman } \\
\text { berusahatani }\end{array}$ & $\begin{array}{l}\leq 10 \text { tahun } \\
>10 \text { tahun }\end{array}$ & $\begin{array}{l}50 \\
50\end{array}$ \\
\hline 3 & $\begin{array}{l}\text { Keaktifan } \\
\text { mencari } \\
\text { informasi }\end{array}$ & $\begin{array}{l}\text { Tidak aktif } \\
\text { Kurang aktif } \\
\text { Aktif }\end{array}$ & $\begin{array}{c}23,3 \\
50 \\
26,7\end{array}$ \\
\hline 4 & $\begin{array}{l}\text { Luas penguasaan } \\
\text { lahan pertanian }\end{array}$ & $\begin{array}{l}<0,5 \text { ha } \\
0,5-1 \text { ha }\end{array}$ & $\begin{array}{l}30 \\
70\end{array}$ \\
\hline 5 & $\begin{array}{l}\text { Keterlibatan } \\
\text { dalam } \\
\text { kelompoktani }\end{array}$ & $\begin{array}{l}\text { Tidak aktif } \\
\text { Kurang aktif } \\
\text { Aktif }\end{array}$ & $\begin{array}{l}80 \\
10 \\
10\end{array}$ \\
\hline 6 & $\begin{array}{l}\text { Interaksi dengan } \\
\text { penyuluh }\end{array}$ & $\begin{array}{l}\text { Tidak pernah } \\
\text { Jarang } \\
\text { Sering }\end{array}$ & $\begin{array}{c}63,3 \\
20 \\
16,7\end{array}$ \\
\hline
\end{tabular}

Namun petani umumnya tergolong usia dewasa awal (early adult) dan dewasa pertengahan (middle adult), yaitu: 26,7 persen berusia 29 - 40 tahun dan 46,7 persen berusia 41 - 64 tahun. Pada usia dewasa awal seseorang punya kemampuan belajar yang cukup tinggi dan pada usia dewasa pertengahan, seseorang masih memungkinkan untuk diberi tambahan pendidikan sesuai dengan pekerjaan yang dilakukan (Feldman, 1996). Pendidikan nonformal yang sesuai dengan kebutuhan dan kondisi petani dapat diberikan sebagai alternatif mengatasi tingkat pendidikan formal yang rendah, misalnya pelatihan-pelatihan tentang usahatani yang berhubungan dengan kegiatan yang digeluti petani. Pengembangan kemampuan sumber daya petani menjadi hal yang mutlak untuk meningkatkan kapasitas petani bagi keberlanjutan usahataninya.

\section{Pengalaman Berusahatani}

Sesuatu yang telah dialami seseorang akan ikut membentuk dan mempengaruhi penghayatan terhadap stimulus sosial. Pengalaman usaha adalah sesuatu yang pernah dialami, dijalani, dirasakan, dan ditanggung oleh petani dalam menjalankan kegiatan usahataninya dengan mengerahkan tenaga, pikiran, dan badan untuk mencapai tujuan usahatani, yaitu produksi yang tinggi. Pengalaman berusahatani yang diukur dalam penelitian adalah lama (tahun) petani dalam berusahatani. Pengalaman berusahatani memiliki peranan yang sangat penting bagi petani dalam membuat keputusan yang terbaik dalam berusahatani.

Petani di Desa Sukaharja Kabupaten Bogor adalah petani yang memiliki mata pencaharian utama berusahatani. Kisaran pengalaman petani adalah 1-20 tahun dengan rata-rata pengalaman berusahatani selama 9,3 tahun. Petani telah memiliki bekal relatif cukup lama untuk menekuni profesi sebagai petani. Proses pembelajaran bertani diperoleh dari orang tuanya secara turun temurun. Terhitung sejak usia remaja atau telah dewasa, biasanya petani sudah memulai menggarap lahan milik orang tuanya. Orang tua memberikan keleluasaan pada anaknya untuk menggarap lahannya sesuai dengan komoditas yang dipilihnya. Umumnya teknik-teknik usahatani yang dikembangkan oleh para orang tuanya terdahulu tidak berbeda jauh dengan teknik-teknik yang dikembangkan oleh anaknya sehingga teknik pertanian yang banyak diterapkan adalah "keterampilan warisan". Sebagaimana Tohir (1983) menyebutkan bahwa dalam mengelola usahatani, petani masih banyak mempergunakan pengalamannya sendiri atau pengalaman orang lain dan juga mempergunakan perasaannya.

Pengalaman dalam pekerjaan (termasuk dalam berusahatani) dengan demikian dapat berupa pengalaman kuantitatif yaitu jumlah tahun bekerja dan pengalaman kualitatif yaitu 'proses kehidupan/belajar' yang dialami selama bekerja (berusahatani) yang dapat mempengaruhi tindakan seseorang. Pengalaman menjadi berkualitas ketika selama jumlah tahun bekerja (berusahatani) terjadi proses belajar dengan panduan yang benar dan terarah. Pola bertani dengan keterampilan warisan yang diterapkan kebanyakan petani di lokasi penelitian mengedepankan konsep common sense dan tanpa panduan berdasarkan uji ilmiah dari suatu konsep bertani. Diperlukan dukungan pihak lain yang berpihak kepada petani (seperti: penyuluh) dan yang terhubung dengan pihak/lembaga penelitian bidang pertanian untuk membantu petani dalam meningkatkan kapasitasnya; sehingga pengalaman kuantitatif petani sejalan dengan pengalaman kualitatif yang berkualitas.

\section{Keaktifan Mencari Informasi}

Keaktifan mencari informasi yang dimaksud dalam penelitian adalah frekuensi petani untuk mencari informasi yang berkaitan dengan kegiatan usahatani, seperti: informasi tentang bibit, teknik budidaya, pupuk, dan harga. Petani semakin memerlukan informasi tentang kegiatan usahatani yang berkembang. Informasi sangat diperlukan untuk mempertahankan dan meningkatkan kualitas kegiatan usahatani.

Keaktifan petani di Desa Sukaharja dalam mencari informasi termasuk kategori rendah (skor: 1,3). Rendahnya keaktifan petani dalam mencari informasi menyiratkan 'miskinnya' inovasi dalam berusahatani dan ketiadaan perkembangan usahatani mengikut keadaan dunia yang berubah cepat. Informasi merupakan faktor penting bagi petani dalam hal penerapan suatu inovasi untuk pengembangan usahatani. Sebagaimana penelitian Ratnasari, dkk. (2012) menunjukkan bahwa informasi 
yang diterima petani menentukan persepsi petani terhadap suatu inovasi. Hal ini diperkuatkan oleh Soekartawi (2005) yang menyebutkan bahwa arus informasi yang diterima petani, menentukan apakah petani menerima atau menolak suatu inovasi yang selanjutnya akan menentukan kualitas kegiatan usahatani.

Terdapat $26,7 \%$ petani yang tetap aktif mencari informasi. Sumber informasi yang paling dekat dengan petani adalah petani lain yang telah berhasil dalam berusahatani, dan sedikit interaksi dengan penyuluh. Petani lebih suka mencari informasi ke sesama petani yang ada di sekitarnya karena sumber informasi tersebut selalu tersedia pada saat diperlukan, petani tidak perlu bepergian jauh untuk mendapatkan informasi. Informasi yang dicari dan dipertukarkan oleh petani adalah informasi yang merupakan masalah sehari-hari petani, seperti: cara budidaya, harga saprodi, harga produk, dan kemana petani dapat menjual hasil panennya. Melalui keaktifan mencari informasi, petani mendapatkan tambahan informasi dan kemampuan baru, memperoleh wawasan yang lebih baik sehingga dapat melakukan caracara bertani yang lebih baik.

\section{Luas Penguasaan Lahan Pertanian}

Lahan pertanian yang dimiliki petani merupakan modal utama dalam berusahatani dan sangat menentukan kemandirian petani dalam menentukan keputusan sendiri yang terbaik bagi pengembangan dan keberlanjutan usahatani. Hal-hal yang berkaitan dengan kegiatan usahatani akan bisa diterapkan atau petani dengan bebas membuat keputusan, jika lahan tersebut milik sendiri. Lahan sewa akan menyulitkan petani untuk bebas membuat keputusan tentang kegiatan usahatani. Luas penguasaan lahan pertanian yang dimaksud dalam penelitian ini adalah luas lahan yang dimiliki oleh petani dan digunakan untuk berusahatani, yang dihitung dalam hektar.

Sebagian besar petani (53,3\%) di Desa Sukaharja menggarap lahan kurang dari satu hektar, sisanya (46,7\%) juga mempunyai lahan 'hanya' satu hektar. Hernanto (1993) membuat klasifikasi kepemilikan lahan di bawah dua hektar termasuk lahan yang tidak luas.

Ketersediaan lahan merupakan salah satu faktor penentu keberlanjutan usahatani; namun petani berusaha menyiasati keterbatasan lahannya. Kegiatan pertanian merupakan pekerjaan yang dikuasainya, sehingga dalam menghadapi lahan yang sempit, petani melakukan upaya dengan cara bertahan di lahan sempit dan melakukan pemanfaatan lahan secara optimal.

\section{Keterlibatan dalam Kelompoktani}

Keterlibatan dalam kelompoktani yang diukur dalam penelitian ini adalah frekuensi keikutsertaan petani dalam pertemuan kelompoktani. Keterlibatan dalam kelompoktani menjadi penting sebagai sarana tempat berinteraksi, berkomunikasi, saling belajar, dan saling bertukar pengalaman antar petani, dan para petani akan memperoleh manfaat dari kegiatan tersebut dalam menunjang usaha pertaniannya.

Petani tergabung ke dalam empat kelompoktani di Desa Sukaharja. Kegiatan yang diselenggarakan oleh kelompoktani adalah berdiskusi membahas agenda kelompok, arisan, dan pengajian agama. Hal-hal yang dibicarakan dalam pertemuan kelompok seperti: kesepakatan menentukan waktu tanam bersama yang efektif (tidak berdampak hama), mengatasi problem hama, pemberian bantuan finansial, dan memberi rekomendasi saprotan, juga melalui media kelompoktani penyuluh mengadakan penyuluhan usahatani.

Keterlibatan petani di Desa Sukaharja dalam kelompoktani masih rendah, hanya sejumlah kecil (20 persen) petani yang mengikuti kegiatan kelompoktani. Semestinya petani terlibat aktif dalam kelompoktani, sehingga kelompoktani menjadi sarana belajar bagi petani. Sebagaimana Slamet (2003) menjelaskan bahwa terjadinya interaksi antar petani dalam kelompok sangat penting sebab merupakan forum komunikasi yang demokratis di tingkat akar rumput. Forum kelompok merupakan forum belajar sekaligus forum mengambil keputusan untuk memperbaiki nasib mereka sendiri. Melalui forum tersebut pemberdayaan dilakukan, yang akan berlanjut pada tumbuh dan berkembangnya kemandirian petani dan tidak menggantungkan nasib dirinya pada pihak lain.

Keaktifan petani dalam kelompoktani juga akan menjadikan kelompoktani menjadi maju dan berkembang dengan aktivitas yang sesuai dengan kebutuhan petani, sehingga pada akhirnya menjadi sarana bagi petani dalam meningkatkan kualitas usahatani. Sebagaimana penelitian Juraemi (2004) yang menemukan bahwa tingkat keterlibatan dan keaktifan petani dalam kelompoktani mempengaruhi tingkat keragaan dan kualitas kegiatan serta kinerja kelompoktani.

Rendahnya keterlibatan petani dalam kelompoktani, menunjukkan bahwa hanya sebagian kecil petani yang dapat mengambil manfaat dari keberadaan kelompoktani; diperlukan penyuluhan untuk memotivasi petani supaya aktif dalam kegiatan kelompoktani.

\section{Interaksi dengan Penyuluh}

Interaksi dengan penyuluh yang diukur dalam penelitian ini adalah jumlah interaksi petani dengan penyuluh untuk mendapatkan informasi tentang usahatani. Interaksi petani di Desa Sukaharja dengan penyuluh masih rendah, sejumlah besar (63,3 persen) petani menyebutkan tidak pernah berinteraksi dengan penyuluh.

Faktor penyebab jarangnya interaksi petani dengan penyuluh, antara lain adalah: (1) penyuluh tidak bertempat tinggal di desa setempat, (2) kegiatan penyuluhan tidak dilakukan secara intensif, dan (3) petani menganggap penyuluh belum banyak 
pengalaman dalam berusahatani. Alasan petani sejalan dengan temuan Agunga \& Chris (2005), bahwa kegiatan penyuluhan sangat berhubungan dengan persepsi petani terhadap penyuluhan.

Penyuluh hanya satu kali dalam sebulan datang mengunjungi desa, sehingga momentum pertemuan antara penyuluh dengan petani sangat terbatas, dan hanya sebagian kecil dari petani yang ikut dalam pertemuan tersebut. Memang terdapat penyuluh swadaya, namun baru diangkat dan belum banyak berkiprah. Temuan ini juga mendukung hasil penelitian yang dilakukan Indraningsih, dkk. (2010) yang menyatakan bahwa penyuluh lebih mengutamakan tugas-tugas administrasi di kantor dan kegiatan di lapangan bersama petani dilakukan bila ada program/ proyek yang membutuhkan penyuluh sebagai pendamping.

Semestinya kegiatan penyuluhan dilaksanakan secara intens, sebagai salah satu sarana interaksi petani dengan penyuluh. Melalui interaksi dengan penyuluh, petani berpeluang mendapatkan informasi baru yang berkaitan dengan kegiatan usahatani dan sekaligus sarana untuk bertukar informasi dalam mengatasi masalah yang dihadapi dalam berusahatani. Diperlukan keikutsertaan petani yang aktif dalam kegiatan-kegiatan penyuluhan dan sekaligus diperlukan kegiatan penyuluhan yang intens serta peningkatan kompetensi penyuluh bagi kualitas kegiatan penyuluhan.

\section{Kemandirian Petani dalam Pengambilan Keputusan untuk Keberlanjutan Usahatani}

Kemandirian petani dalam pengambilan keputusan pengelolaan keuangan pada kategori rendah (skor: 1,2). Sebagian besar $(83,3 \%)$ petani tidak melakukan analisis usaha dan kurang mampu untuk menentukan penerimaan dan pengeluaran dalam kegiatan usahatani.

Keberhasilan usahatani yang kemudian menentukan keberlanjutan usahatani memerlukan pengelolaan keuangan yang teratur dan tercatat. Menurut Slamet (2003), pengelolaan keuangan usahatani merupakan penerapan peran petani sebagai manajer usahatani. Stoner dan Wankel (1986) menyebutkan bahwa perencanaan dan pengelolaan keuangan menentukan dan memegang peranan dalam kelancaran suatu usaha

Tabel 2. Skor kemandirian petani

\begin{tabular}{|c|c|c|}
\hline No & Aspek Kemandirian & Skor \\
\hline 1 & Pengelolaan keuangan & 1,20 \\
\hline 2 & Pemilihan komoditas & 1,41 \\
\hline 3 & Penanganan hasil & 1,22 \\
\hline \multirow[t]{2}{*}{4} & Pemasaran & 1,30 \\
\hline & Rataan & 1,28 \\
\hline
\end{tabular}

$$
\begin{aligned}
& \text { Keterangan: } \mathrm{n}=30 \text {, skor } 1-1,66=\text { rendah } \\
& 1,67-2,33=\text { sedang } \\
& 2,34-3=\text { tinggi }
\end{aligned}
$$

Kemandirian petani dalam pengambilan keputusan pemilihan komoditas pada kategori rendah (skor: 1,4$)$. Sebagian besar $(60 \%)$ petani menentukan jenis komoditas yang ditanam tidak berpedoman pada hukum permintaan dan penerimaan, tetapi hanya berdasarkan kebiasaan serta mengikut komoditas yang ditanam petani lainnya. Temuan ini sejalan dengan pernyataan Slamet (2003), bahwa banyak petani yang mengambil keputusan hanya berdasarkan pengalaman atau tradisi.

Mutu keputusan yang diambil petani dalam berusahatani sangat penting, karena menentukan nasib keberlanjutan usahatani dan nasib keluarga petani. Petani harus membekali diri supaya mampu membuat keputusan yang terbaik. Slamet (2003) menyebutkan bahwa untuk dapat mengambil keputusan yang tepat/baik selain berdasarkan pengalaman, diperlukan pula: informasi, pengetahuan, wawasan, keterampilan, dan keberanian.

Kemandirian petani dalam pengambilan keputusan penanganan hasil pada kategori rendah (skor: 1,2). Sebagian besar $(80 \%)$ petani tidak melakukan perlakuan terhadap produk usahataninya. Petani langsung menjual hasil usahataninya tanpa melalui pencucian, penyortiran, dan pengelompokan (sortasi dan grading), bahkan sebagian menjual ketika masih di lahan dan ada juga tengkulaknya yang memanen langsung.

Kemandirian petani dalam pengambilan keputusan pemasaran pada kategori rendah (skor: 1,3). Petani "terjebak" untuk menjual kepada pedagang pengumpul dan tidak punya pilihan untuk menjual kepada pihak lain. Hal ini karena petani kurang mampu mencari informasi tentang harga hasil panen di tempat lain. Petani tidak mengetahui secara pasti perbandingan harga hasil panen di tempat lain, termasuk harga di tingkat konsumen akhir. Harga ditentukan oleh pedagang pengumpul yang datang, dan petani cenderung tidak punya pilihan lain untuk menjual dengan harga yang lebih baik.

Tingkat kemandirian petani di Desa Sukaharja Kabupaten Bogor termasuk kategori rendah, pada semua aspek kemandirian yang diukur. Petani membutuhkan dorongan dan dukungan supaya dengan kemampuan serta kekuatannya sendiri dapat mengatasi masalah dalam upaya mengembangkan usahataninya. Slamet (2003) menyebutkan, para petani bukannya tidak mau maju dan berkembang, tetapi mereka memerlukan bantuan pihak luar untuk dapat mengatasi berbagai persoalan defisiensi yang dialami.

\section{Korelasi Karakteristik Sosial dengan Kemandirian Petani dalam Pengambilan Keputusan untuk Keber- lanjutan Usahatani}

Keaktifan mencari informasi berhubungan positif nyata dengan kemandirian petani dalam pengambilan keputusan untuk keberlanjutan usahatani. Artinya semakin tinggi frekuensi petani dalam mencari informasi yang berhubungan dengan usahatani maka semakin tinggi pula tingkat kemandirian petani dalam pengambilan 
keputusan untuk keberlanjutan usahatani. Temuan ini sejalan dengan temuan Ningsih (2011) yang menyatakan bahwa akses yang tinggi terhadap informasi menjadikan sumberdaya petani berkualitas. Sumberdaya yang berkualitas adalah kapasitas diri petani yang berkualitas sebagai faktor penting untuk menjadikan petani mandiri.

Keaktifan petani dalam mengakses informasi, melakukan komunikasi dan berhubungan dengan pihak-pihak luar dapat menambah kemampuan petani dalam pengambilan keputusan untuk mengatasi permasalahan yang mereka hadapi dalam kegiatan pengelolaan usahatani yang lebih baik. Akses terhadap informasi usahatani adalah kemampuan petani untuk membuka diri terhadap pembaharuan. Hal ini juga berkaitan dengan perkembangan proses belajar, yang menuntut petani untuk membuka diri mencari informasi dalam berusahatani.

Tabel 3. Korelasi karakteristik sosial dengan kemandirian petani

\begin{tabular}{clc}
\hline No & \multicolumn{1}{c}{ Karakteristik Sosial Petani } & $\begin{array}{c}\text { Koefisien Korelasi } \\
\text { (hubungan dengan } \\
\text { kemandirian petani) }\end{array}$ \\
\hline 1 & Pendidikan formal & 0,094 \\
2 & Pengalaman berusahatani & 0,238 \\
3 & Keaktifan mencari informasi & $\mathbf{0 , 3 6 2 *}$ \\
4 & Luas penguasaan lahan pertanian & 0,058 \\
5 & Keterlibatan dalam & 0,178 \\
6 & kelompoktani & \\
\hline
\end{tabular}

Keterangan: $\mathrm{n}=30$ orang

* Berhubungan nyata pada $\alpha=0,05$

Slamet (2003) menyebutkan kemampuan petani dalam mencari informasi, melakukan komunikasi serta interaksi dengan pihak "pemilik" informasi menjadikan petani memiliki "modal" dalam membuat dan menentukan pengambilan keputusan yang terbaik dalam berusahatani. Uraian di atas menunjukkan bahwa agar kemandirian petani dalam pengambilan keputusan untuk keberlanjutan usahatani dapat meningkat, dapat dilakukan dengan memotivasi petani untuk selalu aktif mengakses informasi dan memastikan tersedianya sumber informasi yang berpihak kepada petani dan informasi yang sesuai dengan kebutuhan serta permasalahan petani.

Interaksi dengan penyuluh berhubungan positif nyata dengan kemandirian petani dalam pengambilan keputusan untuk keberlanjutan usahatani. Artinya semakin tinggi frekuensi interaksi petani dengan penyuluh maka semakin tinggi pula tingkat kemandirian petani dalam pengambilan keputusan untuk keberlanjutan usahatani.

Hal ini dikarenakan, pada setiap pertemuan dan kegiatan penyuluhan, penyuluh berupaya memberikan informasi yang berkaitan dengan usahatani dan terjadi saling tukar informasi antara petani dan penyuluh. Melalui interaksi dengan penyuluh, maka petani di lokasi penelitian berpeluang menggali informasi, mengkonsultasikan permasalahan, mendiskusikan hal-hal baru pada penyuluh, yang pada akhirnya dapat menjadi bekal bagi petani dalam membuat keputusan terbaik dalam berusahatani. Hasil penelitian ini sejalan dengan temuan Malta (2011) yang menyatakan bahwa interaksi petani dengan penyuluh dapat meningkatkan kinerja petani dalam berusahatani yang selanjutnya meningkatkan kemandirian petani.

Peran penyuluh sangat menentukan dalam meningkatkan kemandirian petani. Peran ini semakin penting manakala petani membutuhkan pihak yang mampu membantu dalam proses peningkatan kapasitasnya tanpa harus digurui dan diintervensi oleh pihak lain. Kemampuan penyuluh dalam melaksanakan kegiatan penyuluhan sangat diperlukan dalam proses pengembangan kemandirian petani dalam berusahatani. Sumardjo (2008) menyebutkan penyuluhan merupakan salah satu pilar bagi pengembangan kemandirian individu dan masyarakat, sedangkan penyuluh adalah individu yang mengemban misi penyuluhan tersebut.

Berdasarkan hasil penelitian membuktikan bahwa interaksi petani dengan penyuluh dapat meningkatkan kemandirian petani dalam pengambilan keputusan untuk keberlanjutan usahatani, maka pembangunan masyarakat/ petani di lokasi penelitian dapat dilakukan dengan lebih intensifnya interaksi penyuluh dengan petani melalui kegiatan-kegiatan penyuluhan yang sesuai dengan kebutuhan dan masalah petani.

\section{SIMPULAN}

Faktor yang penting diperhatikan untuk meningkatkan kemandirian petani di Desa Sukaharja Kabupaten Bogor dalam pengambilan keputusan untuk keberhasilan usahatani adalah: keaktifan mencari informasi yang berhubungan dengan usahatani dan interaksi dengan penyuluh. Hal yang disarankan: (1) penyuluh dan ketua kelompoktani supaya selalu dan terus memotivasi petani untuk aktif mengakses informasi yang berhubungan dengan usahatani serta memotivasi petani untuk aktif berinteraksi dengan penyuluh dalam kegiatan penyuluhan, (2) penyuluh dan lembaga penyuluhan mengintensifkan pelaksanaan kegiatan penyuluhan, yaitu penyuluhan yang sesuai dengan kebutuhan dan masalah petani.

\section{DAFTAR PUSTAKA}

Agunga, R \& Chris, I. 2005. Organic Farmers' Need for and Attitude Towards Extension. Journal of Extension 45(6). http://www.joe.org/joe/2005 February/alp.shtml.

Feldman, R.S. 1996. Understanding Psychology. New York: McGrawHill. 
Hernanto, F. 1993. Ilmu Usahatani. Jakarta: Penebar Swadaya.

Hubeis, H.V.S. 2002. Tantangan dan Prospek Teknologi Informasi dan Komunikasi dalam Otonomi Daerah. Dalam: Pambudy, R., dan Adhi, A.K. (ed). Pemberdayaan Sumber Daya Manusia Menuju Terwujudnya Masyarakat Madani (pp. 13-23) Bogor: Pustaka Wirausaha Muda.

Indraningsih, K.S., Sugihen, B.G., Tjitropranoto, P., Asngari, P.S., \& Wijayanto, H. 2010. Kinerja Penyuluh dari Perspektif Petani dan Eksistensi Penyuluh Swadaya Sebagai Pendamping Penyuluh Pertanian. Analisis Kebijakan Pertanian, 8 (4): 303-321.

Juraemi. 2004. Hubungan Antara Kinerja Kelembagaan dengan Keragaan Sistem Agribisnis Pada Perusahaan Inti Rakyat Perkebunan Kelapa Sawit. Jurnal Ekonomi Pertanian dan Perikanan, 1(2): 33-40.

Malta. 2011. Faktor-Faktor yang Berhubungan dengan Kinerja Petani Jagung di Lahan Gambut. Jurnal Mimbar, 27(1): 67-78.

Ningsih, K. 2011. Pengembangan Sumberdaya Manusia Petani. Jurnal Pertanian UIM, 2 (1): 34-45.

Ratnasari, T., Sumarsih, E., \& Heryadi, D.Y. 2012. Pengaruh Tingkat Pendidikan Terhadap Persepsi Masyarakat Tentang Sayuran Organik. Jurnal Pertanian Universitas Siliwangi, 2 (1): 17-30.
Sidi, I.P.S., \& Setiadi, B.N. 2005. Manusia Indonesia Abad 21 yang Berkualitas Tinggi Ditinjau dari Sudut Pandang Psikologi. http//www.himpsi. org.

Slamet, M. 1995. Sumbang Saran Mengenai Pola Strategi dan Pendekatan Penyelenggaraan Penyuluhan Pertanian. Lokakarya Dinamika dan Perspektif Penyuluhan Pertanian, Bogor Juli 4-5.

Slamet, M. 2003. Paradigma Baru Penyuluhan Pertanian di Era Otonomi Daerah, dalam: Yustina, I., dan Sudrajat, A, (ed). Membentuk Pola Perilaku Manusia Pembangunan (pp. 56-67). Bogor: IPB Press.

Soekartawi. 2005. Prinsip Dasar Komunikasi Pertanian. Jakarta: UI Press.

Stoner, J.A.F., \& Wankel C. 1986. Management. New York: Frederick A. Praeger, Inc.

Sumardjo. 1999. Transformasi Model Penyuluhan Pertanian Menuju Pengembangan Kemandirian Petani: Kasus di Propinsi Jawa Barat. Disertasi. Ilmu Penyuluhan Pembangunan, Institut Pertanian Bogor, Bogor.

Sumardjo. 2008. Penyuluhan Pembangunan Pilar Pendukung Kemajuan dan Kemandirian Masyarakat, dalam: Yustina, I., dan Sudrajat, A, (ed). Pemberdayaan Manusia Pembangunan yang Bermartabat (pp. 76-98). Bogor: Sydex Plus.

Tohir, K. 1983. Seuntai Pengetahuan tentang Usahatani Indonesia. Jakarta: Bina Aksara. 